\title{
Michal Bar-Asher Siegal Jewish-Christian Dialogues on Scripture in Late Antiquity: Heretic Narratives of the Babylonian Talmud
}

\author{
(Cambridge: Cambridge University Press, 2019), hardcover, ix + 228 pp.
}

\author{
JOHN MANDSAGER \\ mandsage@mailbox.sc.edu \\ University of South Carolina, Columbia, SC 29208
}

Michal Bar-Asher Siegal's book, a deserving finalist for the National Jewish Book Award (2019), is an excellent companion to her very well-regarded first book, Early Christian Monastic Literature and the Babylonian Talmud (2013). In this book, Bar-Asher Siegal once again studies the Babylonian Talmud and demonstrates that its authors had knowledge of early Christians and polemicized against their views. While her earlier work focused on the local context of early Christian and rabbinic exchange in the Sasanian Empire, her argument in the present work is both broader, in terms of geography and intellectual exchange, and narrower, insofar as she focuses on a particular set of extremely short dialogues in the Babylonian Talmud. In this "mini-corpus," each dialogue includes a min, which she convincingly demonstrates means "heretic" in these cases and which has a semantic range related to Christian heresiological discourses (pp. 5-25). The min interprets a biblical verse only to be called a "Fool!" by a rabbinic sage, who mocks the heretic for his wrong interpretation. Bar-Asher Siegal argues that the rabbis created these dialogues not as historical records of actual encounters between rabbis and heretics. Instead, the rabbis imagine what such encounters might entail and mock and satirize rival theological and exegetical claims.

Her primary task is to discern "what these stories can teach us of the Babylonian Talmudic knowledge of Christian traditions" (p. 5). This requires the deft and careful examination of biblical interpretation across a wide range of both Latin, Greek, and Syriac Christian sources and of Second Temple-period and rabbinic Jewish sources. In each of Bar-Asher Siegal's examples, she must fill in the gap between the foolish interpretation offered by the heretic and the "correct" interpretation of the rabbi. She argues that the scholar can fill this gap by "drawing on 
external knowledge in order to better understand the narrative's content and context" (p. 104).

She begins with an introduction to minim stories (chapter 1) and a study of the use of insults, especially the term "fool," in Second Temple-period and early Christian writings (chapter 2). In each of the following four chapters (chapters 3-6), she considers a single dialogue between a $\min$ and a rabbi where the rabbi mocks the heretic for his wrong interpretation of a biblical verse. For example, in chapter 4, she looks at a dialogue from $b$. Berakhot 10a in which a min has a question about how to interpret a verse in Isaiah (pp. 109-11). The min says, "It is written: 'Rejoice, $\mathrm{O}$ barren one who bore no child' (Isaiah 54:1). Because she did not bear is she to rejoice?" In response, Beruriah calls this heretic a fool and directs his attention to the end of the verse ("For the children of the desolate shall be more than the children of the espoused"). She then claims that Israel shall rejoice because she has not "born children for gehenna," turning barrenness from a sorrowful burden into joy. As Bar-Asher Siegal summarizes, "the reason for the barren woman's joy is the presumed nature of the unborn children. These children are likened to the heretic himself, and since they are destined to hell, the mother is happy that they were never born." This short dialogue raises several questions. Why include the min's question when it is so readily answered by the end of the verse? Why does Beruriah mock him so strongly, calling him a "fool," destined for hell? What can this dialogue tell us about how much rabbis knew about competing interpretations of this verse (Bar-Asher Siegal's overarching question)? Bar-Siegal Asher's analysis follows these questions by presenting different interpretations of the verse from the Targums, Philo, Tannaitic sources, Paul's letter to the Galatians, 2 Clement, and Pesigta deRav Kahana. In Galatians 4:21-31, Bar-Asher Siegal argues, Paul uses Isaiah 54:1 to contrast Sarah and Hagar in the Genesis narrative, contrasting Sarah's miraculous (even non-sexual) conception with Hagar's conception "according to the flesh" (pp. 123-25). "Paul reads the verse in Isaiah not as a description of two stages experienced by one individual, but rather as a synchronic description of two entities (Sarah and Hagar), one of whom is a barren woman with multiple descendants." Sarah, then, is the barren woman who rejoices after her nonsexual conception of Isaac. For Beruriah's harsh mockery of the heretic in $b . \mathrm{Be}$ rakhot 10a to make sense, Bar-Siegal Asher argues, we must assume that the authors of the Talmudic dialogue know that Christians interpret the verse in ways similar to Paul in Galatians (pp. 134-42). The conflict in the dialogue, as in each of the dialogues that Bar-Asher Siegal analyzes, is thus between Christians and Jews. "The $\min$ intends to say: we [Christians] are better because we are the sons of the spirit and are not bound by the commandments. Beruriah responds: we are better precisely because we do keep the commandments and do not end up in gehenna" (p. 142, emphasis original).

Bar-Asher Siegal provides nuanced analyses, relying on a wide range of Jewish and Christian interpretations of biblical verses, in the other chapters of the book. She presents a dispute over the proper interpretation of Amos 4:13, "He who forms the mountains and creates the wind," in chapter 3; of Micah 7:4, "The best of them is like a brier," in chapter 5; and of Hosea 5:6, "He has drawn off from them," in 
chapter 6. Chapter 3 contains the longest of these min dialogues, from $b$. Hullin 87a, which, she argues, remarkably includes two different minim, one "good" and one "bad," each of whom represents a different Christian interpretation of the verse. In this dialogue, "we gain not only knowledge of the rabbinic authors concerning Christian traditions, but also of a nuanced view that is willing to present some minim as closer than others" (p. 104).

Bar-Asher Siegal's individual analyses are quite convincing, and the book as a whole offers an innovative method for considering how much the Babylonian rabbis knew about Christians and forms of Christianity. Yet, as she is quite aware, connecting the dots from extremely short dialogues in the Babylonian Talmud to general and specific Christian claims about theology and about the Hebrew Bible and its interpretation requires speculation. As she concedes, "In most cases, the heretic's words do not expose the full Christian argument I claim lies at their foundation" (p. 187). Rather, Bar-Asher Siegal must supply that larger Christian context. This caution notwithstanding, Bar-Asher Siegal's introduction of convincing Christian hermeneutical arguments opens the door for further investigation of the question, "how much Christianity is there in the Babylonian Talmud?" (p. 191).

This book is a welcome and exciting contribution to the study of the Babylonian Talmud in its late antique contexts. Students and scholars of rabbinic literature and early Christianity will benefit from the innovative methods and interpretations Bar-Asher Siegal deftly provides in this volume. 